\title{
Difficulty of morphological diagnosis in Gram staining
}

\author{
Muneyasu Yamaji, Yoshiki Kusama 다 , Katsunori Kamimura, Toshiro Maihara
}

Department of Pediatrics, Hyogo Prefectural Amagasaki General Medical Center, Amagasaki, Hyogo, Japan

\section{Correspondence to Dr Yoshiki Kusama; stone.bagle@gmail.com}

Accepted 23 July 2021

\section{DESCRIPTION}

A 35-day-old female infant with no apparent perinatal events was presented to our hospital due to fever. Her temperature was $39.2^{\circ} \mathrm{C}$, and sinus tachycardia was noted; yet, her general condition was good, and she presented no abnormal physical findings. Blood examination revealed leucocytosis $\left(22 \times 10^{9} / \mathrm{L}\right)$ and an increase in serum $\mathrm{C}$ reactive protein levels $(45.5 \mathrm{mg} / \mathrm{L})$, and urinalysis revealed a positive leucocyte elastase value (Urinary leucocyte count was not investigated at the time of diagnosis because the test is unavailable in the emergency room). We diagnosed her with urinary tract infection (UTI); however, unexpectedly, urine Gram staining revealed faintly stained, long and thin Gram-negative bacteria; we suspected Psendomonas spp (figure 1). ${ }^{12}$ Although we believe that Pseudomonas spp rarely cause UTIs in a healthy infant, we initiated ceftazidime for Pseudomonas aeruginosa, according to the result of Gram staining. Fever improved 2 days after the initiation of ceftazidime. The result of urine culture was pan-sensitive Escherichia coli (figure 2), and we switched the antibiotic to oral cefalexin. The infant was discharged after the antibiotic switch, and no recurrence was observed in the 2 months after discharge.

In the overall diagnosis of UTI, the sensitivity and specificity of Gram staining have been reported as $81.4 \%$ and $98.2 \%$, respectively, in infants younger than 3 months. ${ }^{3}$ The American Association of Pediatrics recommends Gram staining as a companion to urinalysis for the diagnosis of UTI. ${ }^{4}$ However, another advantage of Gram staining, bacteria estimation, is not well evaluated in adults or in

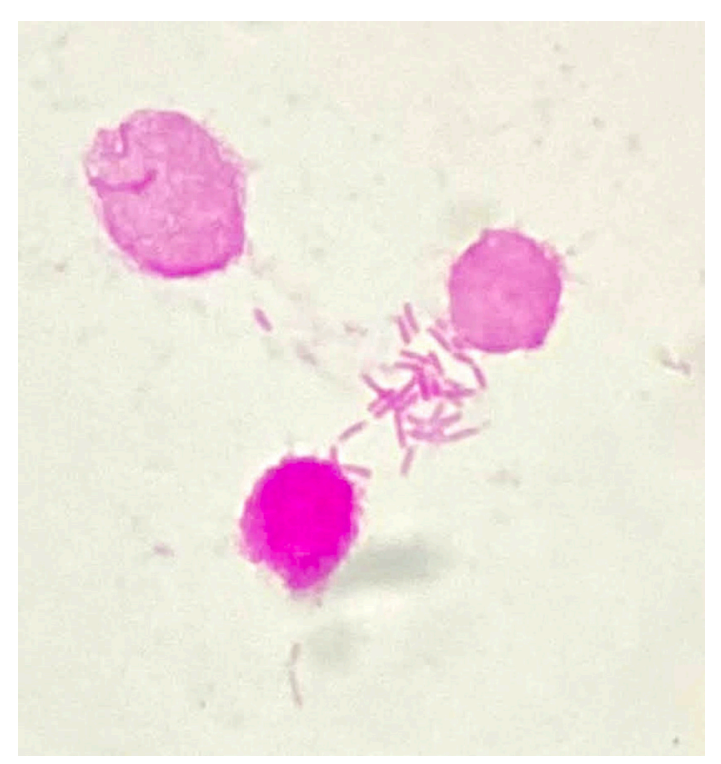

Figure 1 Urine sample. Faintly stained, long and thin Gram-negative bacteria were observed.

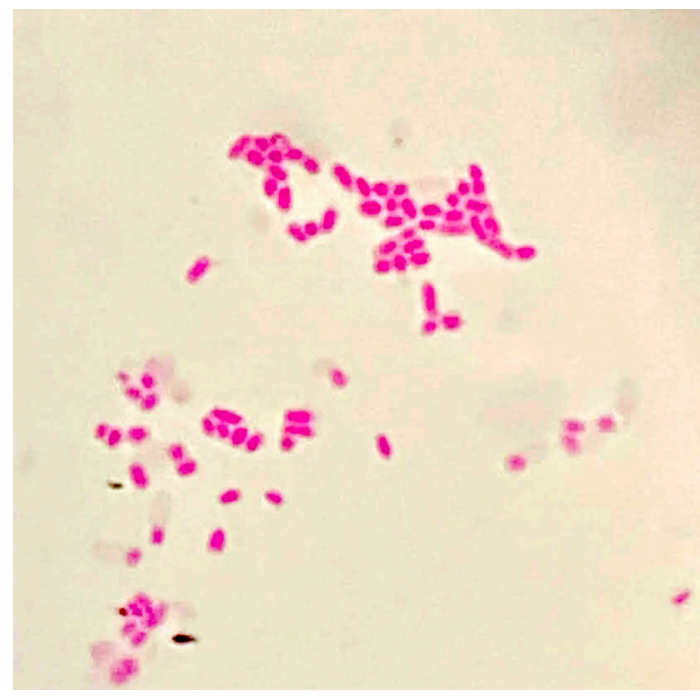

Figure 2 Cultured colony sample: densely stained, almost round-shaped, Gram-negative bacteria were observed.

children. Based on Gram staining, bacteria can be classified into four groups by colour and shape (ie, Gram-positive/negative cocci/bacilli); however, sometimes, bacterial species can be investigated by a detailed observation of morphological characteristics even among the same group. However, this differentiation is generally difficult and needs training and experience. In this case, we mistook $P$. aeruginosa for Enterobacteriaceae as the causative organism based on morphological characteristics, which led to unnecessary broad-spectrum antibiotic administration. This lesson does not apply worldwide because other countries commonly use aminoglycosides that cover $P$. aeruginosa for an infant with UTI (This practice is not quite common in Japan). Nevertheless, it is important to keep in mind the possibility of different morphologies observed in Gram staining. In Japan, the Gram staining technique is one of the attainment targets in the paediatric specialist's certificate programme, to promote antimicrobial stewardship. Educational system involving microbiologists has been established in some teaching hospitals. Gram staining is useful for selecting antibiotics if used wisely ${ }^{5}$; however, we

Learning points

- Bacteria can present differently in situ vs in culture, leading to different diagnoses through examination of morphological characteristics.

- Careful consideration is required when using Gram staining for selecting empiric antibiotics. 
should know the limitation of Gram stain, and exercise caution while interpreting the results.

Contributors MY and YK drafted the manuscript, KK and TM were involved in planning, supervised the manuscript. All authors were involved in diagnosing this patient, and all authors provided critical feedback and helped shape the case report.

Funding The authors have not declared a specific grant for this research from any funding agency in the public, commercial or not-for-profit sectors.

Competing interests None declared.

Patient consent for publication Obtained.

Provenance and peer review Not commissioned; externally peer reviewed.

\section{ORCID iD}

Yoshiki Kusama http://orcid.org/0000-0002-7072-2338

\section{REFERENCES}

1 Marler LM, Siders JA, Allen SD. Direct smear atlas a monograph of gram-stained preparations of clinical specimens. Philaderphia: Lippincott Williams and Wilkins, 1988: 256-7.

2 Church DL. Aerobic Bacteriology. In: Leber AL, ed. Clinical microbiology procedures Handbook. Washington, DC: ASM Press, 2016: 3.0.1-11.

3 Yodoshi T, Matsushima M, Taniguchi T, et al. Utility of point-of-care gram stain by physicians for urinary tract infection in children $\leq 36$ months. Medicine 2019;98:e15101.

4 , Roberts KB, Subcommittee on Urinary Tract Infection, Steering Committee on Quality Improvement and Management. Urinary tract infection: clinical practice guideline for the diagnosis and management of the initial UTI in febrile infants and children 2 to 24 months. Pediatrics 2011;128:595-610.

5 Ohnishi T, Mishima Y, Matsuda N, et al. Clinical characteristics of pediatric febrile urinary tract infection in Japan. Int J Infect Dis 2021;104:97-101.

Copyright 2021 BMJ Publishing Group. All rights reserved. For permission to reuse any of this content visit https://www.bmj.com/company/products-services/rights-and-licensing/permissions/

BMJ Case Report Fellows may re-use this article for personal use and teaching without any further permission.

Become a Fellow of BMJ Case Reports today and you can:

- Submit as many cases as you like

- Enjoy fast sympathetic peer review and rapid publication of accepted articles

Access all the published articles

Re-use any of the published material for personal use and teaching without further permission

Customer Service

If you have any further queries about your subscription, please contact our customer services team on +44 (0) 2071111105 or via email at support@bmj.com.

Visit casereports.bmj.com for more articles like this and to become a Fellow 